\title{
Effect of Pomacea canaliculata snail feed on carcass physical composition, meat chemical composition, and hematological profile of muscovy duck
}

\author{
Ni Luh Gede Budiari*, Yusti Pujiawati, I Putu Agus Kertawirawan, and I Nyoman Adijaya \\ Assessment Institute for Agricultural Technology (AIAT) Bali, Indonesia
}

\begin{abstract}
This study was aimed to evaluate the use of Pomacea canaliculata meal at various levels on the carcass physical composition, meat chemical composition, and haematological profile of Muscovy duck. There were four treatments included P0 (control feed), P1 (control feed + $10 \%$ Pomacea canaliculata meal), P2 (control feed $+20 \%$ Pomacea canaliculata meal), P3 (control feed $+30 \%$ Pomacea canaliculata meal). The variables observed included final body weight, carcass weight, carcass yield, non-carcass weight, meat chemicals composition and haematological profile. The experimental design used a completely randomized design with analysis of variance and further orthogonal polynomial trials. The research results revealed that using golden snail meal in Muscovy duck feed had a significant effect $(\mathrm{P}<0.05)$ on the final body weight, carcass weight, carcass yield, commercial cuts composition, physical composition of the carcass, non-carcass composition, and heterophil. Descriptively, the meat chemicals composition of Muscovy duck with Pomacea canaliculata meal was better than the control. The use of $30 \%$ golden snail meal in the male Muscovy duck diet provides the best performance on final body weight, slaughter weight, carcass yield, and drumstick weight parameters without negatively impacting haematology profile. The use golden snail meal provides the lowest carcass fat.
\end{abstract}

\section{Introduction}

Muscovy duck is a type of waterfowl with a high growth rate and carcass productivity. The Ministry of Agriculture in 2019 stated that population of muscovy duck in Bali Province in 2019 of 30.214 head, or increases 11,02\% [29]. The Statistic Indonesia showed that Muscovy duck is included in the twelve largest types of livestock in the Bali Province [37]. Muscovy duck meat has a higher protein content than ducks and has a better incubate rate than native chicken $[2,40]$. The meat of muscovy duck is known as high-quality meat because it contains low fat and a savoury and specific taste $[15,5,19]$. Generally, many Muscovy ducks in Bali province are kept under extensive and semi-intensive rearing systems. The ducks are herded to find a location for feed sources such as rice fields or swamps to reduce production costs

* Corresponding author: budiariluhde@yahoo.co.id 
because most duck farmers are part of mixed farmers [13]. Therefore, the productivity of Muscovy duck is under optimal, and nutritious and inexpensive feed ingredients are needed. In the poultry industry, the main feed proteins sources are soybean meal and meat bone meal. Both protein source is import commodities, and it was caused poultry feed be unstable. Based on data from the Ministry of Trade in 2020 regarding the import value for the food industry dregs, including soybean meal and meat bone meal, it was 2,910.8 million US\$. On the other hand, the soybean meal portion in poultry ration ranges from $10-20 \%$. Based on these issues, it is necessary to explore alternative feed protein sources of cheap and quality to replace soybean or meat bone meal.

The golden apple snails (Pomacea canaliculata) are paddy plant pests that can reduce productivity ranges $16-40 \%$ [18]. However, golden apple snails can also be used as a protein source feed because they have a crude protein (CP) content of more than $20 \%$. The nutrient components of golden apple snail meal is CP 46,2\%, metabolism energy (ME) $1920 \mathrm{kcal} / \mathrm{kg}$, calcium (Ca) 2,98\% and phosphor (P) 0,35\% [18]. Snails had a lower methionine amino acid than a fish meal but better than a soybean meal [34]. Therefore, raising waterfowl such as Muscovy duck can also reduce the attack of snails pest. On the other hand, waterfowl also get protein source feed.

The study of golden snails as a feed protein source for poultry has been carried out. The use of $15 \%$ golden snail meal in broiler chicken shows a better feed conversion ratio than control [14]. The addition of a $20 \%$ golden snail meal to native chicken rations produced the highest final body weight and lower feed conversion [27]. In quail, $8 \%$ golden snail meal in the diet can increase egg production and decrease feed conversion ratio[41]. The use of golden snail meal of 5\% with $10 \%$ cassava leaf meal in duck diet had the greatest effects on the performance and egg physical quality without affecting the chemical quality of egg [38]. The high protein content of the golden snail also indicated to impact the physical and chemical composition of the carcass and meat. [6] stated that the use of $10 \%$ Pomacea canaliculata from the tidal swampy area achieves the highest meat protein content and lower meat cholesterol content than control feed. In addition, a 15\% golden snail meal was also able to improve the percentage of carcass and reduce abdominal fat in Mojosari-Peking duck [9].

Information about the level of golden snail meal use in muscovy duck ration is still limited.. The study by [18] states that $100 \%$ substitutions of fish meal by golden snail meal in the diet do not affect product performance and carcass percentage. Therefore, further studies are needed to determine the optimal use of golden snails as a protein source feed for production performance, carcass physical composition, meat chemical composition, and haematological profile.

\section{Materials and methods}

\subsection{Animal and dietary treatments}

The experiment used 64 male Muscovy ducks of 8 weeks of age. The experiment was conducted in a completely randomized design with four treatments and four replications, whereas each replicate consisted of four male Muscovy ducks. The Muscovy ducks were allocated randomly in a floor pen. Provided the diet and drinking water were ad libitum. The feeding is done twice in the morning (06.30 a.m) and evening ( 5 p.m) with the same amount. The diet ingredients used were corn, rice bran, pollard, coconut meal, golden snail meal (Table 1) and nutrient content in diet presented in Table 2. The golden snail use dis a pest of rice plants in the Gulingan Village, Mengwi District, Badung Regency. Gold snails are 
collected from farmers, cleaned then steamed and removed from the shell. The golden snail meat is dried in an oven at $105^{\circ} \mathrm{C}$ until it is dry and milled until it becomes meal.

\subsection{Variables and sampling}

The variables measured were final body weight, slaughter weight, carcass weight, carcass yield, commercial cuts composition (thigh, drumstick, brisket, breast, wings), carcass physical composition, non-carcass composition (lungs, heart and intestine), meat chemical composition and haematology profile. Carcass data were obtained by cutting the Muscovy duck at the end of the study. The animals to be slaughtered first have fasted for 12 hours, but drinking water is still provided. According to the [41] method, the slaughter of animals will be carried out while separating the body part of muscovy duck, namely by removing the digestive tract, internal organs, cutting the legs and head until the carcass is obtained.

Haematological parameters measured included haemoglobin content, erythrocyte count, leukocyte count, and blood hematocrit content. Blood sampling was carried out at the end of the study (week 7). Blood samples were taken in the morning before gave the diet. The blood sample was taken through the pectoralis vein as much as $6 \mathrm{ccs}$ and put in an anticoagulant tube. Haemoglobin calculation was done by using the Sahli method. Meanwhile, the hematocrit was determined by measuring the volume of erythrocytes using a microcapillary hematocrit reader. The number of erythrocytes is calculated using a hemocytometer. The blood is first diluted with Hayem's solution 200 times and then read using a counting chamber with the aid of a 10x40 magnification microscope. The blood was diluted using a brilliant cresyl blue (BCB) $0.03 \%$ and then counted with a counting chamber under a microscope with a magnification of 10x40 times to count blood leukocytes. The formula used to count erythrocytes and leucocytes is presented below :

The number of erythrocytes $=a \times 10^{4}$

$a=$ the number of cells counted in the hemocytometer

The number of leukocytes $=b x 50$

$b=$ the number of cell counted in the hemocytometer

Table 1. Composition of ingredients diet

\begin{tabular}{|l|c|c|c|c|}
\hline \multirow{2}{*}{\multicolumn{1}{|c|}{ Feed Ingredients }} & \multicolumn{4}{|c|}{ Treatments } \\
\cline { 2 - 5 } & P0 & P1 & P2 & P3 \\
\hline Corn & 35 & 35 & 35 & 35 \\
\hline Rice Bran & 30 & 15 & 15 & 15 \\
\hline Pollard & 20 & 20 & 15 & 10 \\
\hline Coconut Meal & 15 & 15 & 15 & 15 \\
\hline Golden Snail Meal & 0 & 10 & 20 & 30 \\
\hline Total & 100 & 100 & 100 & 100 \\
\hline
\end{tabular}

Table 2. Nutrient composition of treatments diet

\begin{tabular}{|l|c|c|c|c|}
\hline \multirow{2}{*}{ Nutrient Content } & \multicolumn{4}{c|}{ Treatments } \\
\cline { 2 - 5 } & P0 & P1 & P2 & P3 \\
\hline Energy Metabolism (Kcal/kg) & 3121.90 & 2946.90 & 2872.40 & 2847.40 \\
\hline Crude Protein (\%) & 13.78 & 17.48 & 19.41 & 22.81 \\
\hline Ether Extract (\%) & 5.51 & 5.09 & 5.15 & 5.01 \\
\hline Crude Fiber (\%) & 7.57 & 5.92 & 5.7 & 5.15 \\
\hline Calcium (\%) & 0.06 & 0.5 & 0.65 & 0.79 \\
\hline Phosporus (\%) & 0.65 & 0.44 & 0.46 & 0.38 \\
\hline
\end{tabular}




\subsection{Statistical analysis}

The study used a completely randomized design with four treatments and three replicates. There were four treatments included P0 (control feed), P1 (control feed $+10 \%$ Pomacea canaliculata meal), P2 (control feed $+20 \%$ Pomacea canaliculata meal), P3 (control feed + $30 \%$ Pomacea canaliculata meal). The data were subjected to analysis of variance (ANOVA). When found the significant effect of treatment, Polynomial Orthogonal Test was used to a decided used optimal level of Pomacea canaliculata meal.

\section{Results and discussion}

\subsection{Effect of golden snail meal on body weight and carcass yield}

The use of golden snail meal at various levels in diet affected the final weight, cut weight, and carcass percentage (Table $3 ; \mathrm{P}<0.05$ ). The highest final weight parameter was found in the use of $30 \%$ snail flour in the diet, which was 2847.33 grams $/$ head $(\mathrm{P}<0.05)$ This is because the crude protein content in snail meal is very high, ranging from $46.2-51 \%[18,1]$. In line with the increase in the level of snail meal in the diet, the crude protein content in the diet will also increase (Table 2). The crude protein content until $22 \%$ in the diet has the most significant impact on the final bodyweight of the muscovy duck. If the crude protein content in the diet is increased, there are two possibilities of positive and negative impacts. The negative impact occurs due to the increase in protein content which can reduce feed intake. [12] Stated that protein level and dietary energy impact final body weight, but a diet with high protein $(\mathrm{CP}=22 \%)$ and high energy $(3200 \mathrm{Kcal})$ produces the lowest final body weight in ducks. Based on this, it is necessary to carry out further research by increasing the usage rate by more than $30 \%$.

Slaughter weight, carcass weight, and carcass yield $(\% \mathrm{BW})$ were influenced by the level of use of golden snail meal (Table $3 ; \mathrm{P}<0.05$ ). Found the highest weight parameters in Muscovy ducks which fed $30 \%$ golden snail meal in the diet. [39] stated that the increase in slaughter weight, carcass percentage, and carcass meat percentage occurs due to better metabolic processes occurring in the body and more nutrients that the body can utilize to continuity of various processes in the body. [21] stated that slaughter weight is strongly influenced by differences in the type of ration and the composition and nutrient content in the ration given. The more protein is absorbed, the more protein is deposited in the meat, increasing the final weight [3]. This study showed that use of snail meal until $30 \%$ in the diet did not harm productivity performance.

Table 3. Effect of Level golden snail meal on final body weight, slaughter weight, carcass weight, and carcass yield

\begin{tabular}{|l|c|c|c|c|}
\hline \multirow{2}{*}{ Parameter } & \multicolumn{4}{|c|}{ Treatment } \\
\cline { 2 - 5 } & $\mathrm{P} 0$ & $\mathrm{P} 1$ & $\mathrm{P} 2$ & $\mathrm{P} 3$ \\
\hline $\begin{array}{l}\text { Final body weight } \\
\text { (gram/head) }\end{array}$ & $2449.67^{\mathrm{a}}$ & $2525.67^{\mathrm{ab}}$ & $2687.67^{\mathrm{bc}}$ & $2847.33^{\mathrm{c}}$ \\
\hline $\begin{array}{l}\text { Slaughter Weight } \\
\text { (gram/head) }\end{array}$ & $1932.67^{\mathrm{a}}$ & $2082.67^{\mathrm{a}}$ & $2512.67^{\mathrm{b}}$ & $2557.67^{\mathrm{b}}$ \\
\hline $\begin{array}{l}\text { Carcass weight } \\
\text { (gram/head) }\end{array}$ & $1585.67^{\mathrm{a}}$ & $1643.67^{\mathrm{a}}$ & $1777.67^{\mathrm{ab}}$ & $1925.00^{\mathrm{b}}$ \\
\hline$\%$ Carcass yield & $64.69^{\mathrm{a}}$ & $65.01^{\mathrm{ab}}$ & $66.10^{\mathrm{ab}}$ & $67.69^{\mathrm{b}}$ \\
\hline
\end{tabular}




\subsection{Effect of golden snail meal on composition commercial cuts}

The average commercial cut yield of the carcass (\%) is presented in Table 4. In general, the commercial cut yield is not influenced by the level of use of golden snail meal, except the drumstick variable $(\mathrm{P}<0.05)$. The parameters of slaughter weight and carcass weight are positively influenced by adding the level of golden snail meal. Still, for the parameter of the percentage of each part of the commercial cut to body weight, there is no significant difference $(\mathrm{P}>0.05)$. The present finding is in agreement with those of [26] who reported that there was no significant difference in carcass characteristics (wing, breast, back, thigh, drumstick) by high protein content in the duck diet (18\% vs. $22 \%$ ). Commercial cuts were not significantly different due to the different ratios of energy and protein in rations for each treatment. In P0 and P1 treatment have a high energy content in ration, meanwhile in P2 and P3 treatments have high protein content (Table 3). This shows that the protein or energy in the ration has the same impact on the commercial cut of carcass.

Table 4. Effect of level golden snail meal on commercial cuts composition

\begin{tabular}{|l|c|c|c|c|}
\hline \multirow{2}{*}{ Parameter } & \multicolumn{4}{|c|}{ Treatments } \\
\cline { 2 - 5 } & P0 & P1 & P2 & P3 \\
\hline Thigh (\%) & $15.43^{\mathrm{a}}$ & $15.98^{\mathrm{a}}$ & $16.08^{\mathrm{a}}$ & $16.27^{\mathrm{a}}$ \\
\hline Drumstick (\%) & $11.03^{\mathrm{a}}$ & $11.70^{\mathrm{ab}}$ & $12.10^{\mathrm{b}}$ & $12.21^{\mathrm{b}}$ \\
\hline Brisket (\%) & $28.56^{\mathrm{a}}$ & $29.42^{\mathrm{a}}$ & $29.98^{\mathrm{a}}$ & $29.76^{\mathrm{a}}$ \\
\hline Breast (\%) & $25.39^{\mathrm{a}}$ & $26.88^{\mathrm{a}}$ & $27.62^{\mathrm{a}}$ & $27.51^{\mathrm{a}}$ \\
\hline Wing (\%) & $15.31^{\mathrm{a}}$ & $16.63^{\mathrm{a}}$ & $16.79^{\mathrm{a}}$ & $16.85^{\mathrm{a}}$ \\
\hline
\end{tabular}

The use of $20 \%$ and $30 \%$ golden snail meal in the diet resulted in the highest drumstick yield compared to other levels $(0 \%$ and $10 \%)$. This was due to P2 and P3 treatments having a higher protein content than $\mathrm{P} 0$ and $\mathrm{P} 1$ treatments. Protein content in diet has more effect on thigh yield than energy [12]. Furthermore, this impact is due to the high lysine content in the golden snail meal. Pomacea canaliculata contains amino acids leucine, lysine phenylalanine + tyrosine, threonine, valine, and isoleucine higher than ideal protein [35]. Lysine level 1.1\% produces the highest percentage of thigh and breast of Muscovy duck compared to levels $0.7 \%$ and $0.9 \%[28]$.

\subsection{Effect of golden snail meal on physical composition of carcass}

The physical composition parameters of the carcass, such as meat, bone, skin, and meat : bone ratio, were not affected by the level of use of golden snail meal ( $\mathrm{P}>0.05$; Table 5$)$. The present finding is in agreement with those of [12], who reported that there was no significant difference in the physical composition of carcasses such as meat, bone, skin, and the ratio of meat : bone with substitution golden snail meal to fish meal up to $100 \%$. In contrast to the study according to [33] stated that dietary CP concentration and AA density had an impact on body weight and duck breast meat yield at 28,32 , and 35 days of age where ducks fed with $19 \%$ protein content produced the highest body weight and breast meat yield compared to ducks that are fed with a protein content of 15 and 17\%. Meat yields various because of genetic, age, sex, nutritional, and environmental factors [4]. The ratio factor of the energy and protein content in the ration is indicated to cause the carcass parameters to be not significantly different.

The fat carcass yield was affected by the level of use of golden snail meal $(\mathrm{P}<0.05$; Table 5). Use golden snail meal of $20 \%$ and $30 \%(19,41 \%$ and $22.81 \% \mathrm{CP})$ in diet produces the lowest fat carcass of $3.42 \%$ and $3.33 \%$. This is because $\mathrm{P} 2$ and $\mathrm{P} 3$ diets contain high protein while $\mathrm{P} 0$ and $\mathrm{P} 1$ contain high energy. The high energy content in the ration increases carcass abdominal fat deposition [26]. According to a study by [33] who showed ducks fed the 
highest protein $(19 \% \mathrm{CP})$ and lowest energy $(11.8 \mathrm{MJ} / \mathrm{kg})$ produces a lower fat weight and breast skin than dietary high energy and low protein.

Table 5. Effect of level golden snail meal on physical composition of carcass

\begin{tabular}{|l|c|c|c|c|}
\hline \multirow{2}{*}{ Parameters } & \multicolumn{4}{|c|}{ Treatments } \\
\cline { 2 - 5 } & P0 & P1 & P2 & P3 \\
\hline Meat (\%) & $61.48^{\mathrm{a}}$ & $62.15^{\mathrm{a}}$ & $62.37^{\mathrm{a}}$ & $62.73^{\mathrm{a}}$ \\
\hline Fat (\%) & $3.69^{\mathrm{b}}$ & $3.65^{\mathrm{b}}$ & $3.42^{\mathrm{a}}$ & $3.33^{\mathrm{a}}$ \\
\hline Bone (\%) & $28.23^{\mathrm{a}}$ & $28.28^{\mathrm{a}}$ & $28.72^{\mathrm{a}}$ & $28.66^{\mathrm{a}}$ \\
\hline Skin (\%) & $6.35^{\mathrm{a}}$ & $6.53^{\mathrm{a}}$ & $6.60^{\mathrm{a}}$ & $6.67^{\mathrm{a}}$ \\
\hline Meat : Bone & $2.18^{\mathrm{a}}$ & $2.21^{\mathrm{a}}$ & $2.19^{\mathrm{a}}$ & $2.23^{\mathrm{a}}$ \\
\hline
\end{tabular}

\subsection{Effect of golden snail meal on non-carcass composition}

The average weight of lungs was not affected by the level of use of golden snail meal $(\mathrm{P}>0.05$ ; Table 6). The present finding agrees with [13], who reported high and low dietary energy and protein levels were not affected on broiler lung weight. However, the average weight of the heart and intestine was affected by using a golden snail meal $(\mathrm{P}<0.05$; Table 6$)$. In this study, the average lung weight ranging from 0.90-1.07 gram/100gr BW. The lung weight in this study was higher than the lung weight presented by [2], who founded lung weight of male muscovy duck of 0.91 gram $/ 100 \mathrm{gr} \mathrm{BW}$. Genetic, sex, and nutritional status thus factor influence organ weight. This case occurred on heart and intestine weight in this study, where heart and intestine weight influenced by the level use of golden snail meal. The duck's heart weight fed golden snail meal in the diet heavier than control. The heart weight of male Muscovy ducks of 0.81 gram/100 gram BW [2]. Dietary high protein content produces heavier heart weight. The present finding agrees with [8], who reported high protein levels in diet produced heavier geese heart weight than moderate or low protein level. The weight of the organ shows the level of work of the organ, in the case of the lung organ it is not affected because there is no increase in the activity of the lungs due to the use of golden snail flour in the ration. This shows that there is no negative effect on growth performance as indicated by the final weight.

Table 6. Effect of level golden snail meal on non-carcass composition

\begin{tabular}{|l|c|c|c|c|}
\hline \multirow{2}{*}{ Parameters } & \multicolumn{4}{|c|}{ Treatments } \\
\cline { 2 - 5 } & $\mathrm{P} 0$ & $\mathrm{P} 1$ & $\mathrm{P} 2$ & $\mathrm{P} 3$ \\
\hline Lungs (gr/100 gr BW) & $0.90^{\mathrm{a}}$ & $1.00^{\mathrm{a}}$ & $1.01^{\mathrm{a}}$ & $1.07^{\mathrm{a}}$ \\
\hline Heart (gr/100 gr BW) & $0.79^{\mathrm{a}}$ & $0.88^{\mathrm{b}}$ & $0.89^{\mathrm{b}}$ & $0.92^{\mathrm{b}}$ \\
\hline Intestine (gr/100 gr BW) & $8.61^{\mathrm{a}}$ & $9.37^{\mathrm{ab}}$ & $9.80^{\mathrm{b}}$ & $9.55^{\mathrm{ab}}$ \\
\hline
\end{tabular}

Golden snail meal use affects the intestine weight of Muscovy ducks $(\mathrm{P}<0.05$; Table 6). The high protein content in golden snail meal resulted in heavier duck intestinal weight compared to the control (P0). In this study, the maximum intestinal weight of $9.37 \mathrm{gram} / 100$ gram $\mathrm{BW}$ on $20 \%(\mathrm{CP}=19.41 \%)$ golden snail meal use level. The present finding agrees with [2], who reported intestinal weight of male muscovy duck of 9.9 gram/100 gram BW. Protein content in diet produces greater body weight gain following by improvement in organs weight gain.

\subsection{Effect of golden snail meal on chemical composition meat}

Based on laboratory analysis results, the chemical composition of Muscovy duck meat consists of $77.53 \%$ water, $0.90 \%$ ash, $16.71 \%$ protein, $2.87 \%$ fat, and $2.00 \%$ carbohydrates. This study's protein and fat content are following the study by [16], who reported protein and 
fat content of Muscovy duck meat of $16.199 \%$ and $2.586 \%$, respectively. The quality of meat is influenced by livestock breed, type of livestock, age, food, maintenance methods, handling livestock before being slaughtered when it is slaughtered, and meat handling before consumption [36].

Table 7. Effect of golden snail meal on chemical composition meat

\begin{tabular}{|l|c|c|c|c|}
\hline \multirow{2}{*}{\multicolumn{1}{|c|}{ Parameters }} & \multicolumn{4}{|c|}{ Treatments } \\
\cline { 2 - 5 } & P0 & P1 & P2 & P3 \\
\hline Water (\%) & 77.53 & 77.00 & 61.70 & 67.03 \\
\hline Ash (\%) & 0.90 & 0.97 & 2.06 & 1.32 \\
\hline Protein (\%) & 16.71 & 18.85 & 20.18 & 21.55 \\
\hline Fat (\%) & 2.87 & 3.54 & 5.84 & 5.92 \\
\hline Carbohydrates (\%) & 2.00 & 3.54 & 4.84 & 4.18 \\
\hline
\end{tabular}

The use of golden snail meal in diet produces high protein content in duck meat than duck meat without addition golden snail meal (Table 7). Meat protein content with addition golden snail meal ranging from $18.85-21.55 \%$, higher than [16]. The level of protein in the diet can affect the meat protein content. The protein mass of thigh meat was higher in native chickens fed [24]. The use of the golden snail meal also affects the fat content of the Muscovy duck meat. The fat content of meat was higher in the Muscovy duck, which fed with $10-30 \%$ golden snail flour $(2.00 \%$ vs $3.54 \% ; 5.48 \% ; 5.92 \%)$. Broiler chicken meat fat mass was higher with high protein in the diet, which also happens in native chicken $[10,30]$

\subsection{Effect of level golden snail meal on haematology profile}

The data of haematology profile presented in Table 4. ( $\mathrm{P}<0.05$; Table 8). PCV, Hb, white blood cell (WBC), and red blood cell not affected by treatments $(\mathrm{P}>0.05$; Table 8$)$. In this study, the average Packed-cell volume (PCV) ranges from 34.00-40.00\%. The average PCV in this study lower than the study by [25], who reported PCV for male muscovy duck of $46 \%$ or an average of $43.59 \%$. However, still appropriate the study by [16], who reported the PCV value of male Muscovy duck in the dry season of $38.38 \%$ and the wet season of $38.70 \%$. The values of hemoglobin $(\mathrm{Hb}), \mathrm{WBC}$, and $\mathrm{RBC}$ are respectively $14.4-15.5 \mathrm{mg} \% ; 1.78-3.63 \mathrm{~mm} 3$ ; 2.2-2.9 106/mm3 (Table 8). In this study, Hb value appropriates the study by [25], who reported $\mathrm{Hb}$ value of muscovy duck of $14.92 \%$. The number of erythrocytes in this study is still appropriate. The study by [16] stated that the number of erythrocytes for muscovy duck in the dry season of $2.46 \mathrm{million} / \mathrm{ul}$, while for the wet season of $2.88 \mathrm{million} / \mathrm{ul}$.

Table 8. Effect of Level golden snail meal on haematology profile

\begin{tabular}{|l|c|c|c|c|}
\hline \multirow{2}{*}{\multicolumn{1}{|c|}{ Parameter }} & \multicolumn{4}{|c|}{ Treatment } \\
\cline { 2 - 5 } & P0 & P1 & P2 & P3 \\
\hline PCV (\%) & $37.5^{\mathrm{a}}$ & $40.00^{\mathrm{a}}$ & $34.0^{\mathrm{a}}$ & $38.0^{\mathrm{a}}$ \\
\hline $\mathrm{Hb}(\mathrm{mg} \%)$ & $15.4^{\mathrm{a}}$ & $15.4^{\mathrm{a}}$ & $15.5^{\mathrm{a}}$ & $14.4^{\mathrm{a}}$ \\
\hline $\mathrm{WBC}\left(\mathrm{mm}^{3}\right)$ & $3.63^{\mathrm{a}}$ & $1.78^{\mathrm{a}}$ & $2.10^{\mathrm{a}}$ & $2.43^{\mathrm{a}}$ \\
\hline RBC $\left(10^{6} / \mathrm{mm}^{3}\right)$ & $2.9^{\mathrm{a}}$ & $2.4^{\mathrm{a}}$ & $2.4^{\mathrm{a}}$ & $2.2^{\mathrm{a}}$ \\
\hline Heterophil (\%) & $20.5^{\mathrm{b}}$ & $9.5^{\mathrm{ab}}$ & $17^{\mathrm{b}}$ & $7.5^{\mathrm{ab}}$ \\
\hline Limfosit (\%) & $62.5^{\mathrm{a}}$ & $70.5^{\mathrm{a}}$ & $62.5^{\mathrm{a}}$ & $68.5^{\mathrm{a}}$ \\
\hline Monosit (\%) & $14^{\mathrm{a}}$ & $14.5^{\mathrm{a}}$ & $10.5^{\mathrm{a}}$ & $20^{\mathrm{a}}$ \\
\hline Eisonofil (\%) & $3^{\mathrm{a}}$ & $5.5^{\mathrm{a}}$ & $10^{\mathrm{a}}$ & $4^{\mathrm{a}}$ \\
\hline
\end{tabular}

Leukocytes are used to measure the ability of animals to defend the body from infection. A low leukocyte count causes a decrease in the immune response. The immune system decreases and is a sign that pathogenic organisms that harm the body begin to attack the 
animal body [7]. Based on the leukocyte differentiation test, it was seen that there was no significant difference between the levels of lymphocytes, monocytes, and eosinophils between treatments. In this study, the lymphocyte count ranges from $62.5-70.5 \%$, higher than [16], who reported the lymphocyte count of male Muscovy ducks in the dry season of $35.38 \%$, while in the wet season of $36.60 \%$. Meanwhile, the lymphocytes count was founded in this study lower than the study by [25] stated that the lymphocytes of Muscovy duck are $79.00 \%$. Lymphocytes are white blood cells that fight bacteria or viruses by producing antibodies. An increase in the number of lymphocytes indicates that there is an increase in body immunity. According to [31], the biggest factors affecting the number of lymphocytes are heat or environmental stress and stress because heat stress results in reduced weight of the thymus lymphoid organs Fabricius bursa, which have an impact on decreasing the number of lymphocytes. Meanwhile, the high number of lymphocytes may have foreign bodies in the form of bacteria, viruses, and parasites that enter the body so that the lymphocytes respond by producing antibodies [7].

Monocyte count was founded from 10.5-20\%, while eosinophils count was 3-10\% (Table 8 ). The Male muscovy duck monocytes count in the dry season of $7.50 \%$, while in the wet season of $7.70 \%$ [16]. Meanwhile, the male muscovy duck eosinophile count in the dry season of $6.25 \%$, and the wet season of $14.20 \%$. There was no significant difference in the haematological profile in this study, possibly due to the fairly good feed protein content in all treatments where the ratio protein is given between $13.78 \%$ (P0) vs $22.81 \%$ (P3). Heterophils have a dual role as antimicrobial, and their hyperactivity can lead to tissue damage in severe inflammation or trauma [11]. The heterophil count was influenced by the use level of golden snail meal, where muscovy duck without fed golden snail meal has a higher heterophil $(20.5 \%)$ than other treatments. Heterophil levels in the starter phase of broiler chickens are lower when given feed with low protein content [23]. This difference may be due to inflammation in the muscovy duck given the P0 diet so that heterophils transmigrate into the inflammation site in large numbers to neutralize pathogens by phagocytosis [20].

\section{Conclusion}

The golden snail meal can be used as a feed protein source to replace soybean meal. The use of $30 \%$ golden snail meal in the male Muscovy duck diet provides the best performance on final body weight, slaughter weight, carcass yield, and drumstick weight parameters without negatively impacting haematology profile. The use of $30 \%$ golden snail meal provides the lowest carcass fat. The effect of using golden snail meal more than $30 \%$ still needs to done further research.

\section{References}

1. Anderson, P. Mather, N. Richardson. Nutrition of the mud crab, Scylla serrata (Forskall). In : G. Allan, D. Fielder. (eds.), Mud Crab Aquaculture in Australian and Southeast Asia, ACIAR Working Paper, 54 (2004).

2. A.B. Omojola, Int. J. Poult. Sci 6, 5 (2007).

3. A.F. Fanani, N. Suthama, B. Sukamto, J. Kedokt. Hewan 10, 1 (2016).

4. Irshad, G. Kandeepan, S. Kumar, A.A. Kumar, M.R. Vishnuraj, V. Shukla, J. Anim. Prod. Adv 3, 5 (2012).

5. A.P. Damayanti, J. Agrol 13, (2006).

6. Subhan, T. Yuwanta, Zuprizal, Supadmo, J. Indonesian Trop. Anim. Agric 40, 4 (2015).

7. B.E. Saputro, R. Sutrisna, P.E. Santosa, F. Fathul, JIPT 4, 3 (2016). 
8. D.E. Abou-Kaseem, E.A. Ashour, M. Alagawany, K.M. Mahrose, Z.U. Rehman, C. Ding, Poult. Sci 98, (2019).

9. D.M. Suci, R. Mareta, N. Y. Hidayatulloh, W. Hermana, JINTP 17, 1 (2019).

10. E. Harumdewi, N. Suthama, I. Mangisah, JSPI 13, 3 (2018).

11. E. Mortaz, S.D. Alipoor, I.M. Adcock, S. Mumby, L. Koenderman, Frontiers in Immunology 9, (2018).

12. E. Sritiawthai, S. Sakulthai, J. Sakdee, C. Bunchasak, J. Applied Sci 13, 2 (2013).

13. F.A.S. Dairo, A.O.K. Adesehinwa, T.A. Oluwasola, J.A. Oluyemi, Efr. J. Agric. Res 5, 15 (2010).

14. G. Jawa, N.K.E. Suwitari, I.G.A.M.P. Sanjaya, SEAS 4, 1 (2020).

15. H. Bakrie, Suwandi, L. Simanjuntak, Wartazoa 13, (2003).

16. Ismoyowati, N. Iriyanti, S.A. Santosa, J. Indonesian Trop. Anim. Agric 37, 4 (2012).

17. Ismoyowati, M. Samsi, M. Mufti, Animal Production 14, 2 (2021).

18. I.W. Tami, I.M Mastika, I.M Nuriyasa, MIP 20, 3 (2017).

19. J.K.Q. Solomon, R. Austin, R.N. Cumberbatch, J. Gonsalves, E. Seaforth, Livest. Res. Rural Dev 18, (2006).

20. K.J. Genovese, H. He, C.L. Swaggerty, M.H. Kogut, DCI 41, (2013).

21. M. Daud, M. Mulyadi, Z. Fuadi, Jurnal Agripet 16, 1 (2016).

22. M.H. Tamzil, Wartazoa. 28, 3 (2018).

23. M. Kamely, W. He, J. Wakaruk, R. Whelan, V. Naranjo, D.R. Barreda, Frontiers in Veterinary Science 7, (2020).

24. M. Samsudin, W. Sarengat, H.N. Maulana, Animal Agricultural Journal 1, 1 (2012).

25. N.J. Okeudo, I.C. Okoli, G.O.F Igwe, Tropicultura 21, 2 (2003).

26. N. K. Behera, L.K. Babu, S.K. Sahoo, S.C. Giri, P. K. Pati, B. Panigrahi, S. K. Joshi, Asian. J. Anim. Sci 10, 1 (2016).

27. N. Prabewi, F. Kurniawan, Suharti, L. Yulianti, Z. Hafid, JIPT 1, 1 (2019).

28. N.T. Linh, N.T.K. Dong, N.V. Thu, LRRD 30,1 (2018).

29. Ministry of Agriculture Republic Indonesia. Muscovy Duck Population by Province. I.D. Ministry of Agriculture Republic Indonesia, (2019)

30. P.R. Mubarak, L.D. Mahfudz, D. Sunarti, JSPI, 13, 4 (2018).

31. Puvadolpirod, Thaxton. Model of physiological stress in chicken. $5^{\text {th }}$ Ed. Quantitative evaluation. Departement of Poultry Science, Mississipi State University, 79, (2000).

32. P. Widiyaningrum, Lisdiana, N.R Utami, J. Indonesian Trop. Anim. Agric. 41, 2 (2016).

33. Q.F. Zeng, P. Cherry, A. Doster, R. Murdoch, O. Adeola, T.J. Applegate, Poultry Science 3, 1 (2015).

34. S.S. Diarra, WPSA 71, (2015).

35. S. Ghosh, C. Jung, V.B. Meyer-Rochow, ANRES 51, (2017).

36. S. Natasasmita, R. Priyanto, D.M. Tauchid. Pengantar Evaluasi Daging. Fakultas Perternakan Institut Pertanian Bogor, (1987).

37. Statistic Indonesia. Results of Cost Structure of Livestock Household Survey. I.D Statistic Indonesia, (2017)

38. Sumiati, A. Darmawan, W. Hermana, Trop. Anim. Sci. J 43, 3 (2020).

39. Sunari, Rukmiasih, P.S. Hardjosworo. Persentase bagian pangan dan non-pangan itik mandalung pada berbagai umur, in Proceedings of Lokakarya Unggas Air. Pengembangan Agribisnis Unggas Air sebagai Peluang Usaha Baru, 6-7 August 2001, Ciawi, Indonesia (2001)

40. Triyantini, Abubakar, I.A.K Bintang, T. Antawidjaja, JITV 2, 3 (1997).

41. United States Departement of Agriculture (USDA). Poultry Guidinganual. U.S. Goverment Printing Office Washington D.C, (1997)

42. V.N.S Siahaan, T.H Wahyuni, A.H Daulay, S.R. Lubis, JPI 8, 3(2020). 